Jurdimas (Jurnal Pengabdian Kepada Masyarakat) Royal

Vol. 5 No. 1, Januari 2022, hlm. 1 - 6

Available online at https:/jurnal.stmikroyal.ac.id/index.php/jurdimas

\title{
PEMILIHAN MATERIAL DAN DESAIN YANG INOVATIF SERTA KREATIF UNIVERSITAS PGRI SEMARANG
}

\author{
Muhammad Budi Haryono ${ }^{*}$, Rizal Dwi Bayuna², Syahrul Mahfudli Rohman², \\ Adetia Rizki Wardana ${ }^{2}$, Nashirul Umam ${ }^{2}$ \\ ${ }^{1}$ Program Studi Teknik Mesin, Universitas PGRI Semarang \\ ${ }^{2}$ Himpunan Mahasiswa Teknik Mesin, Universitas PGRI Semarang \\ email: muhammadbudiharyono@upgris.ac.id
}

\begin{abstract}
Material selection and innovative and creative designs are needed as a medium for reducing production costs by changing the design of a product but still paying attention to the safety of its users. The problem that occurs in the surrounding community is the lack of public knowledge about the selection of materials that can risk accidents that will be experienced by users which can be caused by the material not being strong enough to support the load it gets. Innovative and creative design aims to reduce the mass of the material but still refers to user safety. Inappropriate design can increase the risk of accidents and wasted costs in the production process. The method used in this community service is a material selection workshop and an introduction to machine design using solidworks software. Therefore, this community service will greatly help the community in the Karang-tempel Village, East Semarang District, increase their insight into the selection of materials and innovative designs as an increase in the quality of production and ensure the safety of users.
\end{abstract}

Keywords: creative; desain; inovative; material selection; workshop

\begin{abstract}
Abstrak: Pemilihan material dan desain yang inovatif dan kreatif sangat diperlukan sebagai media pengurangan biaya produksi dengan merubah rancangan suatu produk akan tetapi tetap memperhatikan keselamatan dari penggunanya. Permasalahan yang terjadi di masyarakat sekitar akan kurangnya pengetahuan masyarakat tentang pemilihan material yang dapat berisiko akan terjadinya kecelakaan yang akan dialami pengguna yang dapat disebabkan oleh material tidak cukup kuat untuk menopang beban yang didapatkannya. Desain yang inovatif dan kreatif bertujuan sebagai pengurangan massa dari material akan tetapi tetap merujuk kepada keselamatan pengguna. Desain yang tidak sesuai dapat meningkatkan risiko kecelakaan dan pemborosan biaya pada proses produksi. Metode yang digunakan pada pengabdian masyarakat ini adalah workshop pemilihan material dan pengenalan rancang bangun mesin menggunakan software solidworks. Oleh karena itu pengabdian kepada masyarakat ini akan sangat membantu masyarakat di lingkungan kelurahan Karang-tempel, kecamatan Semarang Timur untuk menambah wawasannya terhadap pemilihan material dan desain yang inovatif sebagai peningkatan kualitas hasil produksi dan menjamin keselamatan dari pengguna.
\end{abstract}

Kata kunci: desain; inovatif; kreatif; pemilihan material; workshop 
Jurdimas (Jurnal Pengabdian Kepada Masyarakat) Royal

Vol. 5 No. 1, Januari 2022, hlm. 1 - 6

ISSN 2614-7912 (Print)

DOI: https://doi.org/10.33330/jurdimas.v5i1.1012

ISSN 2622-3813 (Online)

Available online at https:/jurnal.stmikroyal.ac.id/index.php/jurdimas

\section{PENDAHULUAN}

Rekayasa serentak/Concurrent engineering (CE) mewakili tren utama dalam pengembangan produk selama beberapa dekade terakhir, yang telah mengubah pendekatan akademis dan industri dalam melihat proses pengembangan produk. Ini adalah integrasi dari proses pengembangan produk baru untuk memungkinkan peserta membuat hulu keputusan untuk mempertimbangkan kebutuhan hilir dan eksternal. Karakteristik utama dari proses pengembangan konkuren adalah aktivitas yang tumpang tindih, transfer informasi dalam kelompok kecil, dan penggunaan tim lintas fungsi (Sapuan, 2017). Besi merupakan material utama dan sering digunakan dalam dunia industri disebabkan oleh sifatnya yang sangat kuat, akan tetapi besi memiliki berat yang berlebih dibandingkan dengan alumunium, magnesium, dll. Besi terus mengalami perkembangan seperti di-buatnya besi ringan akan tetapi tetap memiliki kekuatan sesuai standar internasional untuk keselamatan pengguna-nya (Chen, 2017).

Industri manufaktur adalah industri yang bergerak dalam bidang pengolahan bahan baku menjadi barang jadi. Dalam era globalisasi industri manufaktur memegang peranan penting, oleh karena itu setiap industry manufaktur dituntut untuk meningkatkan produksinya baik dari segi proses maupun dari kualitas produk dan biaya produksi juga dituntut pula untuk meningkatkan ketepatan waktu produksi sehingga produk dapat diselesaikan pada waktu yang tepat (Mardwiyanto \& Dwiaji, 2020).

Disebabkan skenario industri saat ini yang sangat kompetitif, perusahaan yang berorientasi pada teknologi saat ini telah membuat suatu penyesuaian sistematis terhadap proses-proses konvensional pengembangan produk terintegrasi, yang bertujuan mencari model bisnis yang lebih menguntungkan. Hal ini bertujuan untuk mengelaborasi proposal untuk menyelesaikan kegiatan formal untuk pengembangan produk baru dalam tenggang waktu yang ditetapkan, baik oleh manajemen senior dan serta pasar itu sendiri dalam batas anggaran, dan hal yang terpenting, menghasilkan profitabilitas tinggi dengan kemungkinan yang terendah (Estorilio, 2020).

Produk inovasi merupakan pengenalan hal baru dari suatu produk maupun servis yang berbeda dari barang sebelumnya yang akan meningkatkan kualitas barang tersebut. Perusahaan memberikan perhatian khusus dalam hal ini. Perusahan perlu memiliki pengetahun dalam menginovasi sebuah produk disebabkan akan memberikan dampak positif dalam marketing performance (Nataya \& Sutanto, 2018).

Ketentuan Standarisasi Nasional Indonesia (SNI) nomor 13 tahun 2020 telah mengatur skema penilaian terhadap produk logam. Dalam penilaian tersebut meliputi kesesuaian produk seperti alat konversi bahan bakar gas, alat pemadam api portable, baut batuan belah jepit baja, blok rem komposit untuk sarana perkeretaapian, katup pintu kuningan berulir dan keran air rumah tangga jenis katup pintu, serta batang dan kawat baja.

Permasalah yang terjadi pada masyarakat di kelurahan Karang Tempel adalah minimnya pengatahuan akan pemilihan material dan desain rancang bangun konstruksi mesin guna meningkatkan keselamatan hingga meningkatkan perekonomian desa dengan keluaran diharapkan masyarakat dapat membuat inovasi-inovasi produk baru dengan tetap mengacu pada SNI. 
Jurdimas (Jurnal Pengabdian Kepada Masyarakat) Royal

Vol. 5 No. 1, Januari 2022, hlm. 1 - 6

ISSN 2614-7912 (Print)

DOI: https://doi.org/10.33330/jurdimas.v5i1.1012

ISSN 2622-3813 (Online)

Available online at https:/jurnal.stmikroyal.ac.id/index.php/jurdimas

\section{METODE}

Kegiatan ini dilakukan secara daring (Zoom dan Youtube) untuk masyarakat kelurahan Karang Tempel, Kecamatan Semarang Timur. Kegiatan tersebut diadakan pada hari Minggu, 11 Oktober 2020. Kegiatan diadakan secara daring disebabkan oleh pandemi Covid19 yang masih terjadi maka acara mengikuti anjuran dari pemerintah untuk mencegah kerumunan disuatu tempat. Metode yang digunakan dalam kegiatan ini merupakan pendidikan masyarakat melalui penyuluhan (Gambar 2) dan simulasi IPTEK.

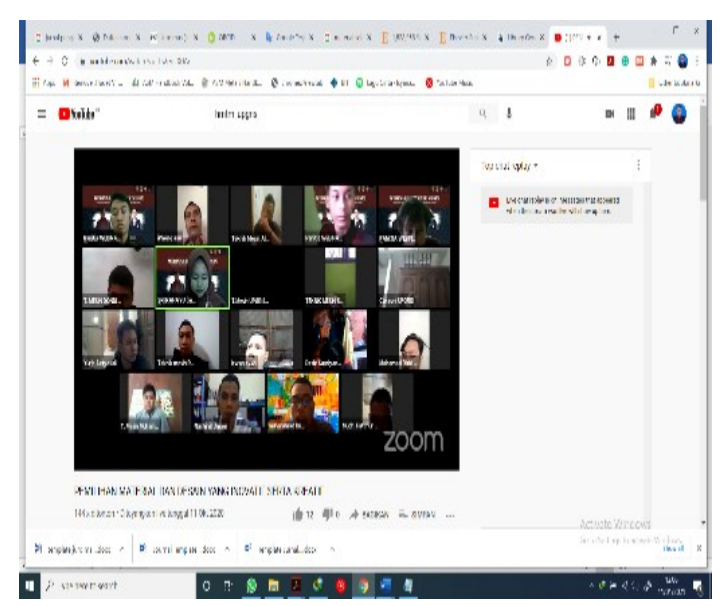

Gambar 1. Daring melalui Youtube

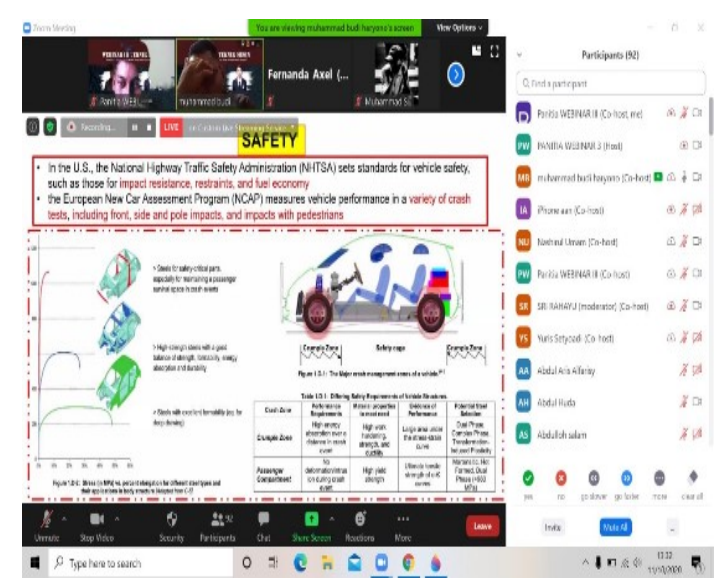

Gambar 2. Penyuluhan pemilihan Material
Untuk memudahkan penyebaran informasi di masa pandemic Covid-19, maka penyebaran kegiatan ini dilakukan melalui media sosial seperti Instagram maupun Facebook (Gambar 3). Kegiatan sosialisasi informasi tentang kegiatan dilakukan oleh Himpunan Teknik Mesin, Universitas PGRI Semarang

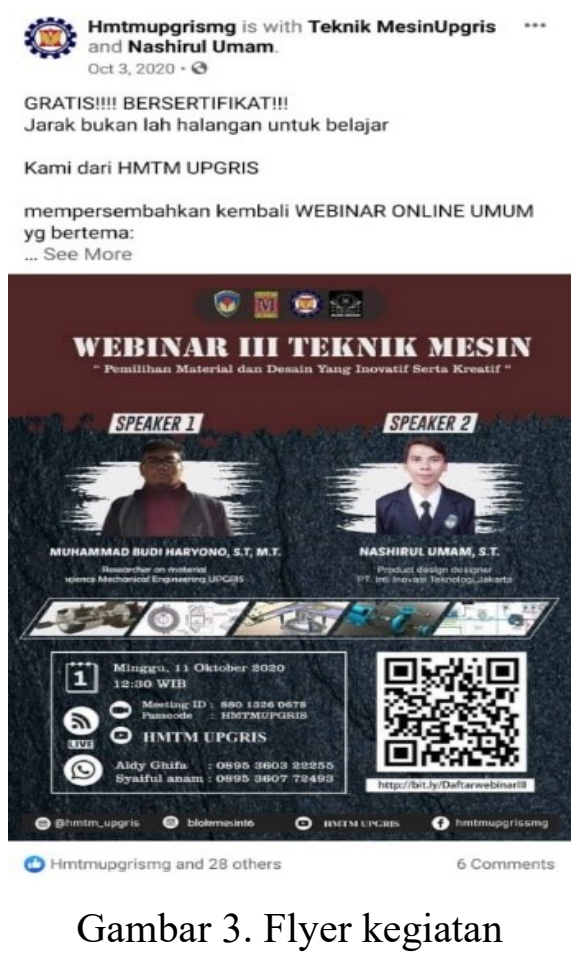

\section{PEMBAHASAN}

Kegiatan ini diawali dengan penyuluhan tentang materi pemilihan material yang bertujuan untuk meningkatkan wawasan warga Kelurahan Karangtampel. Pemilihan material sangatlah penting dikarenakan setiap material memiliki karakteristik yang berbeda meskipun digunakan dalam kasus yang sama. Adapun sosialisasi kegiatan ini diawali dengan pemi-lihan material, pemilihan material yang benar mengacu pada standar buku SNI yang menjamin keselamatan penggunanya. Adapun be- 
Available online at https:/jurnal.stmikroyal.ac.id/index.php/jurdimas

berapa rekayasa proses manufaktur dari material tersebut dapat membantu meningkatan sifat mekanik dari material tersebut sehingga masyarakat dapat mencari solusi dengan mengganti material utama dengan material lain yang berguna menghemat perekonomian.

Adapun sebuah kecelakaan dapat terjadi disebabkan oleh ketidak pahaman produsen ataupun perusahaan dalam proses pemilihan material. Sebuah material dipilih sesuai jenis kasus yang dipilih, standarisasi dari pemilihan material tersebut sudah diatur sebagai mana mestinya baik secara kekuatan fisik, reaksi kimia, dan lain sebagainya. Setelah prooses penyuluhan, panitia dan penonton melakukan proses umpan balik untuk mengetahui respon dari penonton.

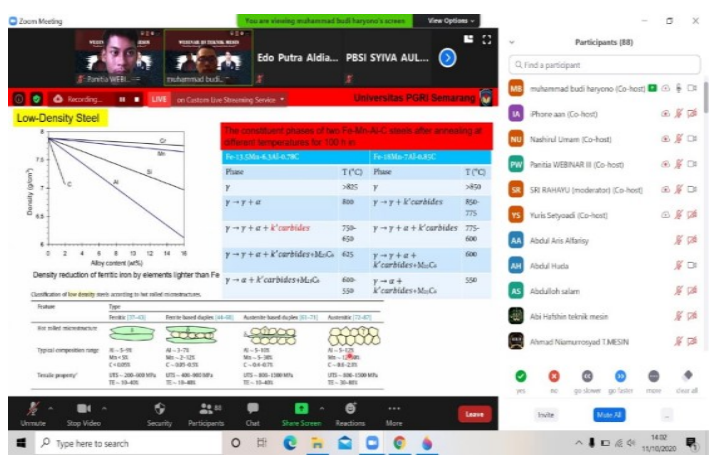

Gambar 4. Acara penyuluhan

Acara selanjutnya, dilakukan oleh perwakilan dari PT Inti Inovasi Jakarta yang mensosialisasikan desain yang inovatif dan kreatif. Dalam acara ini warga diajak berpikir kreatif dan inovatif melalui karya-karya PT Inti Inovasi Jakarta yang bertujuan menghasilkan suatu produk yang efisien dan berkualitas tinggi seperti alat ventilator covid-19. Hal tersebut bertujuan untuk menekan pengeluaran anggaran dari perusahaan. Dalam pemaparan ini, Pemateri memberikan simulasi merancang suatu produk melalui solid- works software. SolidWorks yaitu program rancang bangun yang banyak digunakan untuk mengerjakan desain produk, desain mesin, desain mould, desain konstruksi, dan untuk keperluan lain-lain terkhusus dalam bidang teknik sesuai dengan penelitian yang dilakukan.

SolidWorks dilengkapi dengan tools yang digunakan untuk menghitung dan analisis hasil desain seperti tegangan, regangan, maupun pengaruh suhu, angin, dan lain-lain. SolidWorks sendiri juga merupakan pemodelan yang berbasis fitur parametrik, yang dimana semua objek dan hubungan antar geometrik dapat dimodifikasi kembali meskipun geome-tricnya sudah jadi tanpa perlu mengulang kembali dari awal (Prasetyo, Hermawan, Ridho, Hajar, Hariri, \& Pane, 2021). Software tersebut bertujuan untuk merancang sebuah alat sebelum proses perakitan nyata yang bertujuan mengurangi resiko kegagalan dalam membuat sebuah produk serta mengurangi pengeluaran dana.

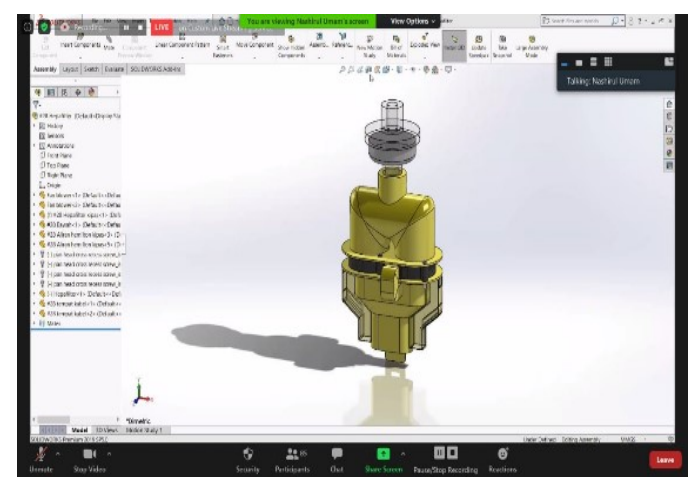

Gambar 5. Simulasi solidworks

Sejalan dengan penelitian (Mardwiyanto \& Dwiaji, 2020) bahwa pemilihan jenis material yang tepat untuk Insert Tool yang telah dilakukan didapatkan model desain insert tool output $2 \mathrm{pcs} /$ proses untuk produksi cutter base di line produksi PT Star Cosmos, 
berdasarkan desain dan simulasi desain Insert Tool maka material carbon steel AISI 1045 yang di pilih untuk Insert Tool, dengan nilai yield strength paling besar.

\section{SIMPULAN}

Warga kelurahan Karangtempel merasa antusias dalam acara ini yang dipraktikan melalui banyaknya pertanyaan yang diajukan oleh penonton. Setelah diadakan acara pengabdian masyarakat ini, dapat diketahui masih terdapat warga yang belum mengetahui proses pemilihan material dan bagaimana menghasilkan desain yang inovatif dan kreatif. Dengan diadakannya kegiatan ini, pemahaman dan wawasan masyarakat telah bertambah sehingga diharapkan dapat melakukan pemilihan material yang tepat serta dapat menghasilkan desain yang inovatif serta kreatif.

\section{UCAPAN TERIMA KASIH}

Ucapan Terimakasih di sampaikan kepada PT Inti Inovasi Jakarta atas kerja sama dalam pelaksanaan kegiatan sosialisasi ini, ucapan terimakasih yang sama kepada Himpunan Mahasiswa Teknik Mesin, Universitas PGRI Semarang yang telah menyelenggarakan acara workshop ini sampai selesai.

\section{DAFTAR PUSTAKA}

Chen, S., Rana, R., Haldar, A., \& Ray, R. K. (2017). Current state of FeMn-Al-C low density steels. Progress in Materials Science,
89 , 345-391. https://doi.org/10.1016/j.pmatsci. 2017.05.002

Estorilio, C. (2020). Highlights There are no relevant tools that associate the Value Engineering ( VE ) concepts, where. Journal of Industrial

Information Integration, 100199. https://doi.org/10.1016/j.jii.2020. 100199

Mardwiyanto, E. A., \& Dwiaji, Y. C. (2020). Analisis Desain Insert Tool Dua Output Untuk Produksi Cutter Base Berbasis Simulasi Statis Software Solidworks 2018 (Doctoral dissertation, Universitas Mercu Buana Jakarta).

Nataya, A., \& Sutanto, J. E. (2018). The Effect of Product Innovation and Service Innovation towards Marketing Performance (Case Study on Plastic Producer in Surabaya). International Journal of Business and Management Invention (IJBMI), 7(8), 61-66.

Penilaian, S., Standar, T., \& Indonesia, N. (2021). gas , alat pemadam api portabel ( APAP ), baut batuan belah jepit baja dan belum mengatur mengenai skema Terhadap Standar Nasional Indonesia Sektor Logam dan ( Lembaran Negara Republik Indonesia Tahun 2018 Tahun 2020 tentang Skema Penilaian Terhadap Standar tentang Perubahan atas Peraturan Badan Standardisasi.

Prasetyo, E., Hermawan, R., Ridho, M. N. I., Hajar, I. I., Hariri, H., \& Pane, E. A. (2020). Analisis Kekuatan Rangka Pada Mesin Transverse Ducting Flange (TDF) Menggunakan Software 
Jurdimas (Jurnal Pengabdian Kepada Masyarakat) Royal

Vol. 5 No. 1, Januari 2022, hlm. 1 - 6

Available online at https://jurnal.stmikroyal.ac.id/index.php/jurdimas

Solidworks. Rekayasa, 13(3), 299-306.

Restu, F., Hakim, R., \& Anwar, F. S. (2017). Analisa Kekuatan Material ASTM A36 Pada Konstruksi Ragum Terhadap Variasi Gaya Cekam Dengan Menggunakan Software SolidWorks 2013. Jurnal
Integrasi, 9(2), 113-118.

Sapuan, S. M. (2017). Concurrent Engineering in Design and Development of Composite Products. In Composite Materials.

https://doi.org/10.1016/b978-012-802507-9.00004-0 